\title{
FOREST INSECT PESTS AND DISEASES IN CANADA
}

\begin{abstract}
N 1935 a Forest Insect Survey was begun in Canada with a small organization located at Ottawa and Fredericton, mainly concerned with European spruce sawfly. It has now expanded to the extent of having 11 laboratories and a permanent staff of 100 employees. In 1957 a Forest Disease Survey was initiated concerning itself with diseases due to organisms and agencies other than insects. Late in 1960, with the formation of a Department of Forestry which absorbed the Forest Biology Division of the Department of Agriculture, a combined survey of all forest diseases became possible.

The size of the annual report for 1960 of the combined survey indicates the extent of the work now being undertaken.* In it each province reports separately, and a rough glance over the index shows that almost 400 individual organisms living on Canadian trees are the subject of record and observation. Compared with tropical rain-forest the number of Canadian tree-species is not large, yet they seem to harbour a considerable number of organisms injurious to them. Not all these are of primary importance, however, and the early spring and hot summer of 1960, except in British Columbia, were not favourable to fungous diseases. A northward spread of butch elm disease in Ontario and New Brunswick was recorded. The major insect marauders are the
\end{abstract}

* Canada: Department of Forestry. Forest Entomology and Pathology Branch. Annual Report of the Forest Insect and Disease Survey, 1960. Pp. 121. (Ottawa: Queen's Printer, 1961.) spruce bud-worm, the larch sawfly and the forest tent caterpillar on aspen, reported from all regions. The bud-worm has severely defoliated spruce and silver fir over an area of nearly 8 million acres in British Columbia.

The survey makes considerable use of aeroplanes for locating certain diseases the distribution and spread of which are shown on appropriate maps. Aerial spraying is used in trying to control the spruce budworm and other insects. The introduction of various insect predators to combat pests like the balsam woolly aphid is on trial, and in Newfoundland a shrew has been introduced, apparently with some success, as a predator on larvæ of the larch sawfly. Quite a number of diseases have been imported from Europe, but not the dwarf mistletoe which infests lodgepole pine in Alberta, and spruce in the Maritime provinces. A damaging ice-storm occurred in Quebec province and frost and storm damage occurred elsewhere.

The minute size of certain organisms is often in inverse proportion to the length of their names. Little did the unsuspecting Indian of a bygone era realize that he was surrounded by such formidable creatures as Pseudexentera improbana oregonana Wlshm. or Lambdina fiscellaria fiscellaria (Guen.). The general value of this annual report would be immensely enhanced if the survey dealt first with the individual organisms in order, using the regions as a secondary basis of reporting and not as the primary one.

M. L. ANDERSon

\section{HEALTH IN YUGOSLAVIA}

$I^{N}$ 1957 the School of Public Health, Zagreb, Yugoslavia, conducted an inquiry into the health, living conditions and social and economic problems of the $\mathbf{8 8 0}$ inhabitants of eleven mountainous villages in the Velebit highlands above the Adriatic coast. The report of the inquiry has now been published by the World Health Organization (WHO Chronicle, 15, No. 7 ; July 1961). These villagers have no roads, no electricity, no radio and no newspapers; the region in which they are has no developed agxiculture or cattle breeding, no industry, or mining. Life is just what it was fifty years ago-simple and hard, perhaps harder, since goat-raising is now forbidden, and the trade in wood, wool and cattle that used to be carried on along the coast has fallen into decay. The young people no longer emigrate to the United States as they used to, but try to get away to other parts of Yugoslavia where conditions are easier.

This situation has left a deep mark on the villages. Since 1900 the population has gone down. In 1900 there were 94 women to 100 men; in 1953 the figure was 112. The average age of the population has gone up, the percentage of people aged 65 and more increasing from $4 \cdot 4$ per cent in 1900 to $11 \cdot 1$ per cent in 1953, the percentage of children aged 14 decreasing from 43.1 per cent to 32.6 per cent in the same period.

Infectious diseases accounted for 46.5 per cent of deaths at the end of the last century. Now they have almost ceased to be a cause of death, the chief causes for 1953-57 being: from infant diseases 35.9 per cent, from old age $33 \cdot 3$ per cent and from pneumonia
10-3 per cent. Infant mortality has always been a serious problem. Cancer and cardiovascular diseases have been responsible for very few deaths.

The majority of cases of respiratory disease found in the investigation lay on the borderline between pathological and the physiological. Diseases of the digestive tract were strikingly low, perhaps because of a diet containing much milk. The nutritional status of the villagers was good. The intestinal parasites found were similar to those of neighbouring districts. Syphilis was diagnosed in only two villagers. Investigation for antibodies to the polioviruses showed that contact with the viruses and immunity to them must have occurred in early childhood. Antibodies against $Q$-fever were found in 26.4 per cent of the population-not surprisingly, as the villagers live in close contact with sheep.

This health study was carried out by teachers and students of the School of Public Health, and, apart from the knowledge it gave of conditions in a remote area, brought the students into contact with the life of the villages, taught them public health techniques, such as analytical methods and sampling, and afforded them opportunity to develop into researchminded workers. It showed that collaboration between university institutions and public health services can be of benefit to both. It also showed that much valuable information can be gleaned in a short time by work such as this and used by the public health authorities as a basis for their health programmes. 